\title{
Dorsal Plate Fixation for Dorsally Displaced Distal Radius Fractures
}

\section{Ki-Tae Na, Seok-Whan Song, Yoon-Min Lee, Byung-Min Kang}

Department of Orthopedic Surgery, Yeouido St. Mary's Hospital, The Catholic University of Korea College of Medicine, Seoul, Korea

Received: February 4, 2014

Revised: March 10, 2014

Accepted: March 11, 2014

Correspondence to: Seok-Whan Song

Department of Orthopedic Surgery, Yeouido St. Mary's Hospital, The Catholic University of Korea College of Medicine, 10 63(yuksam)ro, Yeongdeungpo-gu, Seoul 150-713, Korea TEL: +82-2-3779-1192

FAX: +82-2-783-0252

E-mail: sw.song@catholic.ac.kr

This is an Open Access article distributed under the terms of the Creative Commons Attribution Non-Commercial License (http://creativecommons.org/ licenses/bync/3.0/) which permits unrestricted noncommercial use, distribution, and reproduction in any medium, provided the original work is properly cited.
Purpose: The object of this study is to evaluate the clinical and radiographic outcomes of two different kinds of dorsal plating for dorsally displaced distal radius fractures.

Methods: Forty-three patients with dorsal plate fixation for distal radius fracture were retrospectively reviewed. Twenty-four patients were treated with nonlocking dorsal plate (group I) and nineteen patients with locking dorsal plate (group II). Range of motion and Green and O'Brien score were evaluated as clinical results, and radial inclination, radial length, volar tilt at postoperative and last follow up were evaluated as radiographic results.

Results: According to AO classification system, there were 18 type A fractures, 4 type $\mathrm{B}$ fractures, 21 type $\mathrm{C}$ fractures. In group $\mathrm{I}$, the mean flexion and extension were $65.0^{\circ}$ and $65.3^{\circ}$, respectively; ulnar and radial deviation were $25.5^{\circ}$ and $20.8^{\circ}$; pronation and supination were $80.0^{\circ}$ and $80.4^{\circ}$. In group II, the mean flexion and extension were $64.5^{\circ}$ and $67.3^{\circ}$, respectively; ulnar and radial deviation were $30.6^{\circ}$ and $20.6^{\circ}$; pronation and supination were $81.4^{\circ}$ and $78.6^{\circ}$. The mean Green and O'Brien score was 94.4 in group I and 92.2 in group II, and 41 patients had satisfactory result. There was no statistical significant difference in clinical results between the groups. Results of postoperative and last follow-up radiographic analyses for mean radial inclination were $23.9^{\circ}$ and $24.1^{\circ}$ in group I, respectively, and $24.2^{\circ}$ and $24.9^{\circ}$ in group II; radial length were $9.9 \mathrm{~mm}$ and 9.7 $\mathrm{mm}$ in group I, and $10.1 \mathrm{~mm}$ and $9.2 \mathrm{~mm}$ in group II; mean volar tilt were $12.2^{\circ}$ and $13.1^{\circ}$ in group I, and $14.8^{\circ}$ and $13.7^{\circ}$ in group II . There were no statistical significant changes within radiographic parameters. No extensor tendon rupture was reported.

Conclusion: Dorsal plate fixation for dorsally displaced distal radius fracture showed satisfactory clinical and radiographic outcomes with low complication rate, regardless of the type of plate.

Keywords: Distal radius, Fracture, Dorsal plate

\section{서론 \\ 원위 요골 골절은 상지에서 가장 흔한 골절로 응급실을 방}

문하는 골절 환자의 $1 / 6$ 을 차지한다. 과거에는 대부분의 원위 요골 골절을 도수 정복 후 석고 붕대 고정을 시행하는 비수술 적 방법으로 치료하였다. 그러나 평균 수명의 증가와 원위 요 
골 골절이 흔히 발생하는 노년층의 활동 영역의 확대로 치료 후 수근부 기능에 대한 관심이 높아지고 있다. 또한 많은 연구 에서 원위 요골의 정상적인 방사선학적 지표들을 회복하는 것 이 더 좋은 기능적 결과를 얻을 수 있다고 하여 최근에는 해부 학적 정복 및 유지가 가능한 수술적 방법이 더 선호된다. 원위 요골 골절은 수근부가 과신전 손상되면서 후방 피질골에 분쇄 가 일어나고 후방 전위되는 경우가 많아 과거에는 후방 접근 법을 통한 금속판 고정술을 시행하였다. 하지만 신전 지대를 절개해야 하며, 고정 기구와 신전건의 마찰에 의한 신전건 약 화 및 파열과 같은 합병증 들이 보고되어, 최근에는 수장측 잠 김 금속판을 이용한 고정술이 널리 사용되고 있다. 하지만 골 절의 양상과 상관없이 수장측 금속판을 이용한 도달법을 사용 한다면 해부학적 정복과 충분한 고정이 힘들 수도 있고, 신전 건 혹은 굴곡건의 파열 혹은 자극이나 신경 손상 같은 합병증 이 발생할 수 있다. 또한 최근 후방 금속판 디자인의 향상 및 수술 기법의 발달로 인해 후방 금속판을 이용한 치료가 좋은 결과를 보이고 있고 합병증 또한 줄고 있다 ${ }^{3,4}$. 이에 저자들은 후방 전위된 원위 요골 골절에 대해 두 종류의 후방 금속판을 이용하여 고정술을 시행하였으며, 그에 대한 임상 및 방사선 학적 결과를 보고하고자 한다.

\section{대상 및 방법}

\section{1. 연구대상}

2004년 10월부터 2011년 9월까지 본원에서 원위 요골 골절 로 진단받고 후방 금속판을 이용하여 수술을 시행받은 환자를 대상으로 본원의 연구윤리위원회로부터 연구에 대한 승인을 받은 이후에 후향적 연구를 진행하였다. 후방 금속판 고정술 의 적응증은 수술이 필요한 불안정 원위 요골 골절이면서, 1) 원위 요골의 관절면이 후방으로 전위(전방 각형성)된 경우, 2) 원위 요골 후방에 원위 요골 전후면 길이의 $50 \%$ 이상의 분쇄 가 있는 경우, 3) 후방 골간단부에 골 결손이 있는 경우로 하였 다. 수장측 금속판을 같이 사용하였거나, 동측 상지에 골절이 나 연부조직 손상이 있는 경우, 6 개월 이상 추시가 되지 않은 환자는 연구에서 배제하였다. 골절의 분류는 도수 정복을 시 행하기 전의 수상 초기 단순방사선 사진 및 전산화 단층 사진 소견에 따라 $\mathrm{AO}$ 분류법에 의하여 시행하였다.

본원의 수술 기구 선택에 따른 영향으로 2009년 5월을 기준 으로 그 이전에 수술한 24 명의 환자들은 비잠김 금속판(nonlocking dorsal T-plate, Synthes, Oberdorf, Switzland)을 사용하였으며 이들을 1 군으로 정하였고, 그 이후에 수술한 19 명의 환자들은 잠김 금속판(Periarticular distal radius dor- sal locking T-plate, Zimmer, Warsaw, IN, USA)을 사용 하여 이들을 2 군으로 분류하였다. 임상적 평가는 1 군과 2 군에 서 마지막 추시에서 측정된 관절 운동 범위와 Green and O' Brien score를 비교하였다.

방사선학적 평가는 수술과 관계없는 정형외과 전문의가 각 군에 대해 수술 직후 촬영한 영상과 마지막 추시에서 촬영한 영상에 대해 요측 경사, 요골 길이와 수장 경사를 측정하여 추 시 기간 중 변화를 확인하였다. 수술 후 시행한 단순영상검사 와 전산화단층촬영에서 $1 \mathrm{~mm}$ 이상의 관절면 층형성을 부적 절한 관절면 정복으로 정의하였고, 단순영상 검사에서 골절선 이 없어지면서 골절부위에 골연결이 이루어지는 것을 골유합 으로 정의하였다.

\section{2. 수술 방법}

수술은 환자를 전신 마취한 상태에서 앙와위로 눕히고 전완 부를 회내한 상태에서 수근부 배측의 Lister 결절(tubercle)을 중심으로 근위 및 원위부로 피부 절개를 시행한 후 수근부 신 전 지대가 보일 때까지 박리하였다. 신전 지대는 신전건의 손 상을 조심하면서 Z-모양으로 박리하여 수술 후 재봉합이 가 능하도록 하였다. 이때 요골의 요측 피하 지방층에서 표재 요 골 신경의 손상에 주의하였다. 후방 골간 신경은 제 4 신전 구 획에서 찾아서 수술 후 통증 감소를 위해 제거하였다. 신전건 을 양측으로 벌려 골절 부위를 충분히 노출시키고 Lister 결절 을 제거하였다(Fig. 1). 원위 요골 골절 부위를 정복하고 $\mathrm{K}$-강 선을 이용하여 골절을 임시로 고정한 후 영상증폭장치를 이용 하여 골절 부위의 정복 상태를 확인하였다. 정복이 만족스러 우면 후방 금속판을 원위 요골의 모양에 맞춰 고정하였다. 비 잠김 금속판의 경우 금속판을 원위 요골에 최대한 접착되도록 변형시켰으며, 잠김 금속판의 경우는 금속판 나사 구멍에 만 들어져 있는 잠김 나사못 나선을 보존하기 위하여 금속판 변 형을 하지 않았다(Fig. 2). 관절면의 골절이 있는 경우 후방 관 절낭을 개방하여 관절면 정복 상태를 직접 보면서 정확하게 정복이 이루어졌는지 확인하였으며, 동반 손상이 있으면 동시 에 치료하였다. 금속판 고정 후 Z-모양으로 박리한 신전 지대 를 근위부와 원위부로 나누어, 근위부 절반은 신전건 아래로 위치시켜 금속판의 원위부를 덮어 금속판과 신전건의 마찰을 방지하였고, 나머지 원위부 절반의 신전 지대는 신전 지대의 재건에 사용하였다. ${ }^{5}$ 이때 장 무지 신전건은 신전 지대 위를 지나게 하여 신전 구획 내의 과밀을 방지하였다(Fig. $1 F)$.

관절면의 분쇄가 심하여 외고정기를 사용하는 경우 제 2 중 수골과 요골에 외고정기 나사를 삽입하고, 골절 부위를 도수 정복한 후 수근부를 굴곡 및 척측 변위시킨 상태에서 외고정 


\section{J Korean Soc Surg Hand Vol. 19, No. 1, March 2014}
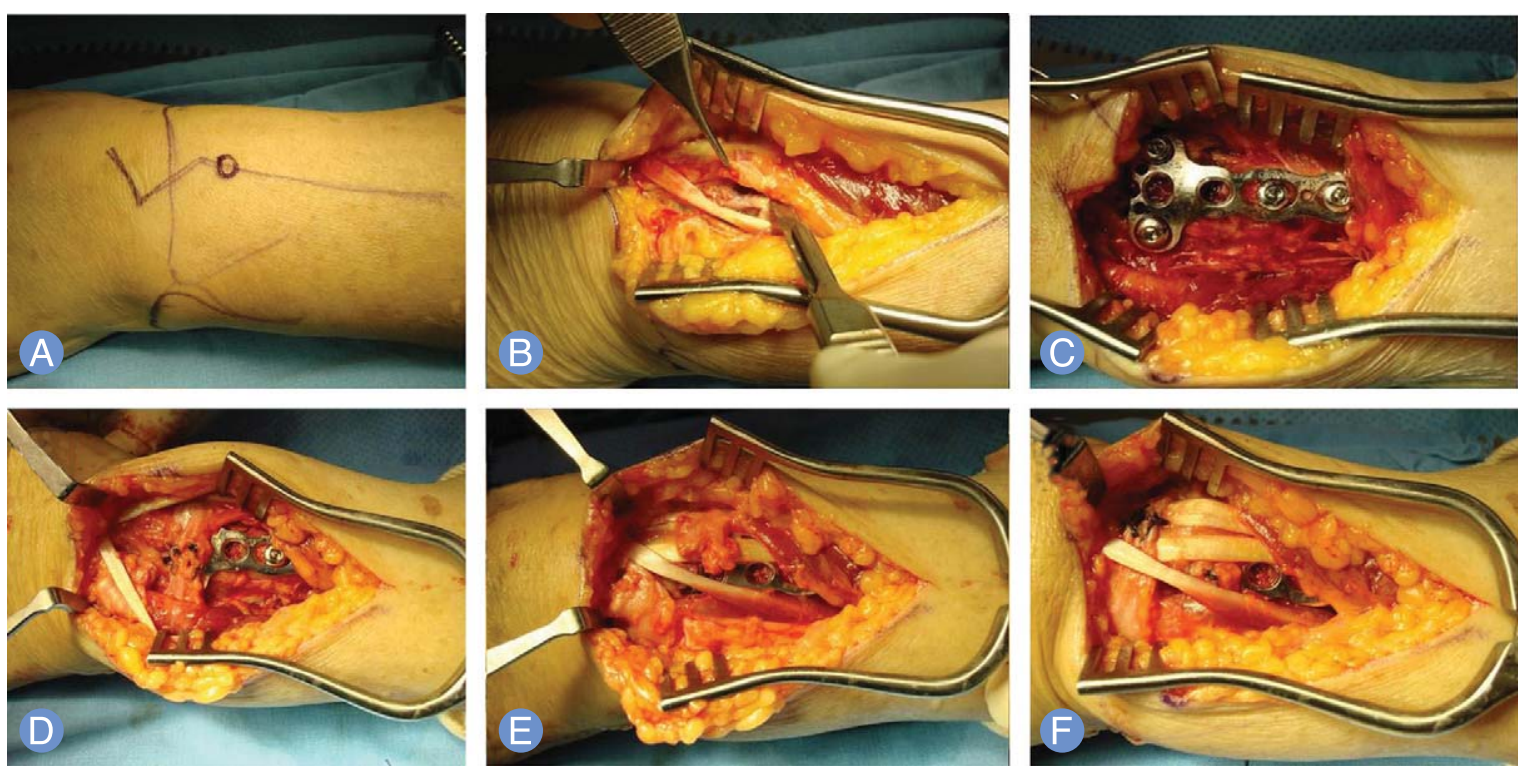

Fig. 1. Dorsal approach for distal radius fracture. (A) Skin incision over Lister's tubercle with zigzag pattern at dorsal aspect of wrist joint. (B) Subperiosteal elevation after dissection of extensor retinaculum. (C) Dorsal plate fixation after the reduction of fracture site and temporary fixation with K-wires. (D) Proximal half of extensor retinaculum was used to cover plate and distal screws. (E) Distal half of extensor retinaculum was repaired. (F) Extensor pollicis longus tendon was placed as subcutaneous.
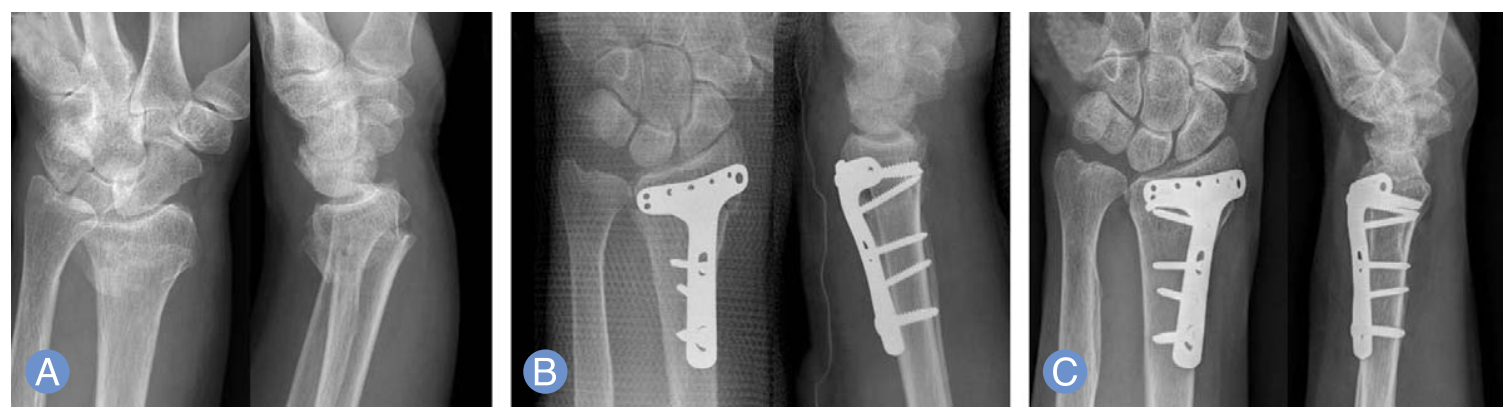

Fig. 2. Sixty-eight-year-old male, with dorsally displaced unstable distal radius fracture, was treated with open reduction and internal fixation using dorsal locking T-plate. (A) Preoperative radiographs show A0 A3 type distal radius fracture. (B) Postoperative radiographs show good reduction and fixation. (C) Twelve months later, radiographs show no interval change.

기를 고정하였으며, 영상증폭장치로 골절 부위의 정복 상태를 확인하였다. 정복이 만족스러우면 요골의 후방을 절개하여 금 속판 내고정을 시행하였으며, 요골 골간단부에 후방 골 결손 이 있는 경우 자가 장골을 이용하여 골이식을 시행하였다. 외 고정기는 수상 당시 골절 부위의 분쇄 정도와 수술 당시 내고 정의 견고성을 고려하여 수술 후 4-6주에 제거하였다. 수술 후 6 개월 이후에는 골유합이 만족스러운 경우 기구를 제거하 는 것을 원칙으로 하였으며, 이는 금속판-금속나사의 부피로 신전건의 움직임이 원활하지 못하거나 이물감이 있을 수도 있 기 때문이었다.

\section{3. 재활}

수지의 능동적 운동은 수술 직후부터 지속적으로 시행하도 록 하였다. 수술 후 3-4주간 전완부 설탕 집게 부목을 착용하 였고 이후 3 주간 단상지 석고붕대를 착용하도록 하였다. 수술 6-7주경 석고 붕대를 제거하고 수근부의 수동적 관절 운동을 시작하면서 3 주간 수근부 보조기를 착용하도록 하였다. 석고 붕대 제거 후에는 수근부 관절 운동 범위를 늘릴 수 있는 운동 을 지속적으로 시행하였다.

\section{4. 통계 분석}

통계 분석은 PASW ver. 18.0 (SPSS Inc., Chicago, IL, 
USA)를 이용하여 실시하였다. 정규성 검정은 Shapiro-Wilk test를 사용하였다. 1 군과 2 군의 관절 운동 범위와 Green and O’Brien score를 비교하기 위하여 독립 표본 T 검증을 사용하였다. 수술 직후와 마지막 추시에서 촬영한 방사선학적 지표의 변화를 비교하기 위해서는 대응 표본 T검증을 사용하 였다. p값이 0.05 이하인 경우 통계적으로 유의한 것으로 하 였다.

\section{결과}

총 43 명의 환자가 본 연구 대상이었으며, 남자가 7 명, 여자 가 36 명 이었고, 평균 연령은 63.3세(범위, 31-81세)이었다. 평균 추시 기간은 15.3 개월(범위, 6-38개월)이었다. 수상 기 전은 넘어진 경우가 39 예, 교통사고 2예, 자전거사고 1예, 산 업재해 1 예이었다. 동반 손상은 총 26예에서 관찰되었으며, 척골 경상 돌기 골절이 22 예로 가장 많았고, 원위 척골 골절이 4 예, 정중 신경 손상과 주상골 골절이 각각 1 예이었다. 두 명 의 환자에서 각각 척골 경상돌기 골절과 정중신경 손상, 원위 척골 골절과 주상골 골절의 두 가지 동반 손상이 확인되었다.

\section{1. 임상적 결과}

골절은 $\mathrm{AO}$ 분류에 따라 $\mathrm{A}$ 형이 18예, $\mathrm{B}$ 형이 4예, $\mathrm{C}$ 형이 21 예이었다. 마지막 추시에서 측정한 수근부 관절 운동 범위는 1
군에서 굴곡 $65.0^{\circ}$, 신전 $65.3^{\circ}$, 척측 변위 $25.5^{\circ}$, 요측 변위 $20.8^{\circ}$, 회내전 $80.0^{\circ}$, 회외전 $80.4^{\circ}$ 이었으며, 2 군에서는 굴곡 $64.5^{\circ}$, 신전 $67.3^{\circ}$, 척측 변위 $30.6^{\circ}$, 요측 변위 $20.6^{\circ}$, 회내전 $81.4^{\circ}$, 회외전 $78.6^{\circ}$ 로, 각 군 사이에 통계학적으로 유의한 차 이는 없었다(Table 1). Green and O’ Brien score에 따른 임 상적 결과는 평균 94.0점(범위, 70-110점)으로, 70점 이하를 기록한 2 예를 제외한 41 예에서 만족스러운 결과를 얻었으며, 1군은 평균 94.4점(범위, 70-110점), 2군은 평균 92.2점(범위, 75-110점)으로 임상적 결과의 각 군 간의 통계학적 유의한 차 이는 없었다(Table 2). 총 8예에서 외고정기를 사용하였으며, 수술 중 골절 부위의 분쇄가 심하여 정복이 잘 유지되지 않았 던 1예의 $\mathrm{A}$ 형 골절을 제외하면 모두 $\mathrm{C}$ 형 골절에서 사용되었 다. 수술 후 불유합이 발생한 경우는 없었으며, 유합 후 기구 제거 수술 이외의 추가 수술이 필요한 경우도 없었다. 감염이 나 신경 손상이 발생한 경우도 없었다. 신전건의 파열이나 자 극으로 인한 증상을 호소한 환자도 없었으며, 수지 운동에 불 편함을 호소하는 환자도 없었다. 총 26 명의 환자가 기구 제거 수술을 받았으며, 제거 시기는 수술일로부터 평균 11.3개월(범 위, 1.5-27개월)이 지난 후 시행하였다. 금속판 제거 수술 시 신전건의 파열이나 자극으로 활액막염이 발생한 경우는 관찰 되지 않았으며, 모든 환자에게서 기구 제거 후 남은 신전 지대 의 봉합이 가능하였다. 후방 금속판 고정술 후 지속적으로 수 근부 통증을 호소하던 1 예에서 수술 후 1.5 개월이 지난 후 제

Table 1. Range of motion

\begin{tabular}{llcll} 
Type of motion & \multicolumn{1}{c}{ Total } & Group I & Group II & $p$-value \\
Flexion $\left({ }^{\circ}\right)$ & $65.8(25-90)$ & $65.0(25-90)$ & $64.5(40-90)$ & $0.958^{*}$ \\
Extension $\left(^{\circ}\right)$ & $66.2(30-90)$ & $65.3(30-90)$ & $67.3(30-90)$ & $0.825^{*}$ \\
Ulnar deviation $\left(^{\circ}\right)$ & $27.4(0-45)$ & $25.5(0-35)$ & $30.6(15-45)$ & $0.515^{*}$ \\
Radial deviation $\left(^{\circ}\right)$ & $20.7(5-40)$ & $20.8(5-40)$ & $20.6(5-35)$ & $1.0^{*}$ \\
Pronation $\left(^{\circ}\right)$ & $80.7(40-90)$ & $80.0(40-90)$ & $81.4(50-90)$ & $0.837^{*}$ \\
Supination $\left(^{\circ}\right)$ & $79.3(40-90)$ & $80.4(40-90)$ & $78.6(40-90)$ & $0.650^{*}$ \\
\hline
\end{tabular}

Values are presented as mean (range).

*Independent t-test (between group I and group II).

Table 2. Functional outcomes

\begin{tabular}{lcccc}
\hline Green and 0 Brien score & Total & Group I & Group II & $p$-value \\
Pain (0-25) & $21.5(15-25)$ & $20.8(15-25)$ & $22.3(15-25)$ & - \\
Range of motion (5-25) & $21.4(10-25)$ & $21.4(10-25)$ & $21.4(15-25)$ & - \\
Occupation (0-25) & $19.7(5-25)$ & $21.1(15-25)$ & $17.7(5-25)$ & - \\
Grip power (0-10) & $6.8(5-10)$ & $6.7(5-10)$ & $6.9(5-10)$ & - \\
X-ray (0-25) & $24.3(20-25)$ & $24.4(20-25)$ & $24.1(20-25)$ & - \\
Total & $94.0(70-110)$ & $94.4(70-110)$ & $92.2(75-110)$ & $0.659^{\star}$ \\
\hline
\end{tabular}

Values are presented as mean (range).

*Independent t-test (between group 1 and group 2). 
J Korean Soc Surg Hand Vol. 19, No. 1, March 2014

거 수술을 시행하였으며, 수술 시 신전건의 파열이나 자극으 로 인한 이상 소견은 관찰되지 않았고, 통증을 일으킬만한 병 변은 발견되지 않았다. 수술 후 통증은 감소하였으며, 적절한 보조기 보호로 성공적인 골유합을 얻었으나 관절 운동 범위나 임상적 기능 평가에서 지속적으로 좋지 않은 결과를 보였다.

\section{2. 방사선학적 결과}

수술 직후 및 마지막 추시 방사선학적 검사에서 요골 경사 는 1 군이 각각 $23.9^{\circ}$ 와 $24.1^{\circ}, 2$ 군은 $24.2^{\circ}$ 와 $24.9^{\circ}$ 이었으며, 요골 길이는 1 군이 각각 $9.9 \mathrm{~mm}$ 와 $9.7 \mathrm{~mm}, 2$ 군이 $10.1 \mathrm{~mm}$ 와 $9.2 \mathrm{~mm}$ 이었다. 수장 경사는 1 군이 각각 $12.2^{\circ}$ 와 $13.1^{\circ}, 2$ 군은 $14.8^{\circ}$ 와 $13.7^{\circ}$ 이었다. 모든 측정치들이 추시 중 통계학적 으로 유의한 변화는 없었고, 후방 금속판을 이용한 고정술이 충분한 고정 강도를 가지는 것으로 나타났다(Table 3). 정복 후의 층형성은 관찰되지 않았으며, 골유합은 수술 후 평균 2.8 개월(범위, 1.5-7.2개월)이 소요되었다.

\section{고찰}

최근 원위 요골 골절 치료를 위한 다양한 전방 금속판의 개 발과 그에 따른 양호한 결과를 보고하는 논문이 많이 발표되 고 있어 많은 수부외과 의사들이 전방 금속판 고정을 선호하 고 있는 경향이다. 그러나 저자들은 후방으로 전위된 원위 요 골 골절편은 후방으로 접근하면 보다 쉽게 정복할 수 있고 분 쇄가 동반된 후방 피질골에 금속판을 고정하므로 생역학적으 로 강한 고정이 가능하다. 이 경우 전방 피질골은 분쇄가 거의 없어 잘 정복되면 그 자체가 안정성을 가진다고 할 수 있다. 또한 관절면을 침범한 골절의 경우 직접 관절면을 시야에서
확인하고 정복할 수 있고, 신전건의 손상이나 동반된 수근골 간 인대의 손상 혹은 삼각 섬유 연골판 손상도 직접 확인해서 필요할 경우 같이 수술을 시행할 수 있으며, 후방 골간단부에 골결손이 발생한 경우 쉽게 골이식을 시행할 수 있다는 장점 으로 후방 도달법을 선호하고 있다. 또한 전방에 위치한 방형 회내근의 도움으로 후방에서 삽입된 나사못 끝에 의한 굴곡건 의 손상은 거의 없다. 이런 장점들로 인해 초기 원위 요골 골 절의 수술적 치료로 많은 후방 금속판이 소개되었으나, 높은 합병증 발생을 보고하는 몇몇 논문들이 발표된 이후 그 사용 이 줄어들었다 ${ }^{6-10}$. Axelrod와 McMurtry ${ }^{6}$ 는 후방 금속판(Tplate, Synthes Ltd., Paoli, PA, USA) 고정술 후 50\% (초기 합병증 $(15 \%)$, 후기 합병증(35\%)의 높은 합병증 발생률을 보고 하였으며, 이런 높은 합병증을 극복하기 위해 pi plate (Synthes Ltd.)가 개발되어 몇몇 논문에서 좋은 임상적, 방사 선학적 결과를 보고하였담. 하지만, Chiang 등레 에 따르면, 20 명의 원위 요골 골절 환자에서 pi plate를 사용한 결과 9 명 (45\%)의 환자는 수술 후 수근부의 지속적인 통증이 발생하여 금속판 제거술이 필요하였고, 3 명(15\%)의 환자는 수술 부위의 지속적인 통증을 호소하였다고 하였다. 다른 연구에서는 신전 건의 파열이 보고되기도 하였으며, 이는 수술과정에서 금속판 의 모양을 원위 요골의 모양에 맞추기 위해 변형시키거나 일 부를 잘라내는 과정에 의해 발생하는 것으로 알려져 있담.

이러한 후방 금속판 고정에 따른 합병증을 피하기 위하여 수장측 금속판에 대한 관심이 커졌으며, 수장측 잠김 금속판 의 발전과 함께 후방으로 전위된 원위 요골 골절에 대해서도 수장측 잠김 금속판을 이용하여 내고정술을 시행하고자 하는 시도가 많았다. Orbay와 Fernandez ${ }^{14}$ 는 31 예의 후방 전위된 원위 요골 골절에서 수장측 고정 금속판을 이용하여 치료를

Table 3. Changes in radiographic parameters

Total

$\begin{array}{llcc}\text { Postoperative } & 24.0 \pm 4.22 & 10.0 \pm 2.44 & 13.2 \pm 8.2 \\ \text { Latest follow-up } & 24.4 \pm 4.04 & 9.5 \pm 3.0 & 13.3 \pm 7.7 \\ \text { p-value } & 0.523^{*} & 0.091^{*} & 0.930^{*} \\ \text { Group I } & & & 12.2 \pm 8.47 \\ \text { Postoperative } & 23.9 \pm 4.50 & 9.9 \pm 2.50 & 13.1 \pm 7.63 \\ \text { Latest follow-up } & 24.1 \pm 4.70 & 0.528^{*} & 0.248^{*} \\ \text { p-value } & 0.801^{*} & 10.1 \pm 2.45 & 14.8 \pm 7.89 \\ \text { Group II } & & 9.2 \pm 1.70 & 13.7 \pm 8.15 \\ \text { Postoperative } & 24.2 \pm 3.97 & 0.084^{*} & 0.844^{\dagger}\end{array}$

*Paired t-test; ${ }^{\dagger}$ Wilcoxon signed ranks test. 
시행하였을 때 좋은 임상 및 방사선학적 결과를 보였다고 하 였다. 또한 Musgrave와 Idler ${ }^{15}$ 도 비슷한 증례에서 좋은 결과 를 보고하였다. 하지만 수장측 접근법은 관절내 골절인 경우 관절면을 직접 보면서 정복할 수 없으며, 동반 손상을 확인하 거나 같이 치료하기도 힘들다. 또한 수장측 잠김 금속판이 발 전하였다 하더라도 분쇄가 발생한 후방에 금속판 고정을 시행 하는 것보다 고정력이 약해 고정 실패가 일어날 수 있다. 흔히 수장측 금속판은 후방 금속판보다 신전건 손상에 안전한 것으 로 알려져 있으나 후방으로 튀어 나온 나사못의 끝부분이 신 전건을 자극하여 파열시키는 경우도 흔히 보고되고 있으며 ${ }^{2}$, 이를 극복하기 위하여 수술 중 및 수술 후 신전건 주위로 튀어 나온 나사못을 확인하기 위한 여러 가지 시도들이 이루어지고 있다 ${ }^{16,17}$. 후방 금속판 고정의 경우 방형 회내근이 나사못의 끝 부분에 대해 보호하여 굴곡건의 손상 가능성이 아주 낮으나, 수장 금속판의 원위 단(transverse ridge)이 분수령(watershed line)보다 원위부에 위치할 경우 굴곡건의 자극 혹은 파 열을 일으킬 수 있다.

많은 연구에서 후방 금속판의 가장 흔한 합병증으로 보고하 고 있는 신전건 파열이나 자극으로 인한 증상은 본 연구에서 는 관찰되지 않았으며, 기구 제거 수술을 시행한 경우에도 신 전건의 파열이나 손상은 관찰되지 않았다. 본 연구에서는 잠 김 금속판뿐만 아니라 이전 모델의 비잠김 금속판도 사용되었 으나 이전 연구와는 다르게 신전건 관련 합병증이 발생하지 않은 것은 신전건을 보호하기 위하여 최대한 원위 요골의 모 양에 맞춰 금속판을 변형시켰으며, 금속판에 의한 자극이 주 로 이루어지는 금속판 원위부("T" 모양의 가로 부분)를 신전 지대의 절반을 이용하여 덮어주고 마찰을 방지하려는 노력에 의한 것으로 보인다.

최근 후방 금속판의 장점은 살리면서 그동안 문제가 되었던 합병증을 줄일 수 있는 얇은 두께(low profile)의 후방 잠김 금 속판들이 많이 개발되었으며 이를 이용한 좋은 결과들을 보고 하고 있다. Kamath 등이 30명의 환자를 대상으로 최근 개발 된 얇은 후방 금속판을 사용하여 원위 요골 골절을 치료한 연 구에서 관절 운동 범위는 정상 측의 굴곡 $81 \%$, 신전 $88 \%$, 회 내전 $89 \%$, 회외전 $87 \%$ 를 보였고, 악력과 집기력은 각각 $78 \%$ 와 $94 \%$ 의 양호한 임상적 결과를 보였으며, 그 외 최근에 비슷 한 연구들도 좋은 결과들을 보고하고 있다 ${ }^{18,19}$.

본 연구에서 비잠김 후방 금속판과 잠김 금속판의 관절 운 동 범위 및 임상 결과, 방사선학적 결과가 통계적으로 유의한 차이를 보이지 않은 것은, 수술 후 약 6 주간의 장-단 부목 고 정으로 골절 부위의 안정성이 어느 정도 이루어진 뒤 관절 운 동을 시작한 점, 골 결손이 있는 경우 대부분의 환자에서 자가
장골 이식으로 관절면 및 분쇄 골절 부위의 함몰이 최소화된 점, 외래 추시 시에 관절 운동 회복을 극대화하기 위하여 외래 시간에 수근부 관절 운동을 외래 담당의가 지속적으로 관리한 점이 효과를 보였다고 생각되며, 비록 잠김 기능이 없는 단순 금속판이라도 유용하게 사용될 수 있었다는 의미를 가진 것으 로 생각된다.

본 연구의 한계로는 증례수가 43예로 각 군으로 나누었을 때 그 증례수가 비교적 적었고, 추시 기간이 평균 15.3 개월이 며, 최소 추시 기간이 6 개월로 짧아 장기적으로 발생할 수 있 는 외상 후 관절염의 발생 유무 등에 대하여 알기 힘든 점 등 이 있었다. 또한 수장측 금속판 고정술과의 비교가 이루어지 지 않았으며, 적은 증례수로 인해 골절의 분류에 따른 비교가 되지 않아 이를 보완하기 위하여는 더 많은 수의 증례를 대상 으로 장기 추시가 필요할 것으로 생각된다.

\section{결론}

원위 요골 골절 후 후방으로 전위된 원위 요골 골절편에 대 하여 후방 금속판 내고정으로 양호한 결과를 얻을 수 있었다. 고전적인 비잠김 후방 금속판 내고정과 최근 개발된 잠김 금 속판 내고정의 임상 및 방사선학적 결과는 통계적으로 유의한 차이를 보이지 않았으며, 이는 수술 후 부목 고정과 골 이식 등의 부가적인 치료 방법에 의한 영향으로 판단되었다. 후방 전위된 원위 요골 골절의 후방 금속판 고정술은 관절면의 해 부학적 정복을 얻을 수 있고 양호한 임상 및 방사선학적 결과 를 얻을 수 있는 좋은 치료 방법으로 생각된다.

\section{REFERENCES}

1. Graff S, Jupiter J. Fracture of the distal radius: classification of treatment and indications for external fixation. Injury. 1994;25 Suppl 4:S-D14-25.

2. Benson EC, DeCarvalho A, Mikola EA, Veitch JM, Moneim MS. Two potential causes of EPL rupture after distal radius volar plate fixation. Clin Orthop Relat Res. 2006;451:218-22.

3. Kamath AF, Zurakowski D, Day CS. Low-profile dorsal plating for dorsally angulated distal radius fractures: an outcomes study. J Hand Surg Am. 2006;31:1061-7.

4. Yu YR, Makhni MC, Tabrizi S, Rozental TD, Mundanthanam G, Day CS. Complications of low-profile dorsal versus volar locking plates in the distal radius: a comparative study. J Hand Surg Am. 2011; 36:1135-41. 
5. Osada D, Tamai K, Iwamoto A, Fujita S, Saotome K. Dorsal plating for comminuted intra-articular fractures of the distal end of the radius. Hand Surg. 2004;9:18190.

6. Axelrod TS, McMurtry RY. Open reduction and internal fixation of comminuted, intraarticular fractures of the distal radius. J Hand Surg Am. 1990;15:1-11.

7. Ring D, Jupiter JB, Brennwald J, Buchler U, Hastings $H$ 2nd. Prospective multicenter trial of a plate for dorsal fixation of distal radius fractures. J Hand Surg Am. 1997;22:777-84.

8. Carter PR, Frederick HA, Laseter GF. Open reduction and internal fixation of unstable distal radius fractures with a low-profile plate: a multicenter study of 73 fractures. J Hand Surg Am. 1998;23:300-7.

9. Jupiter JB. Plate fixation of fractures of the distal aspect of the radius: relative indications. J Orthop Trauma. 1999;13:559-69.

10. Jupiter JB, Fernandez DL. Complications following distal radial fractures. Instr Course Lect. 2002;51:203-19.

11. Campbell DA. Open reduction and internal fixation of intra articular and unstable fractures of the distal radius using the AO distal radius plate. J Hand Surg Br. 2000; 25:528-34

12. Chiang PP, Roach S, Baratz ME. Failure of a retinacular flap to prevent dorsal wrist pain after titanium Pi plate fixation of distal radius fractures. J Hand Surg Am. 2002; 27:724-8.
13. Kambouroglou GK, Axelrod TS. Complications of the $\mathrm{AO} / \mathrm{ASIF}$ titanium distal radius plate system (pi plate) in internal fixation of the distal radius: a brief report. J Hand Surg Am. 1998;23:737-41.

14. Orbay JL, Fernandez DL. Volar fixation for dorsally displaced fractures of the distal radius: a preliminary report. J Hand Surg Am. 2002;27:205-15.

15. Musgrave DS, Idler RS. Volar fixation of dorsally displaced distal radius fractures using the 2.4-mm locking compression plates. J Hand Surg Am. 2005;30:743-9.

16. Haug LC, Glodny B, Deml C, Lutz M, Attal R. A new radiological method to detect dorsally penetrating screws when using volar locking plates in distal radial fractures. The dorsal horizon view. Bone Joint J. 2013; 95B:1101-5.

17. Lee SK, Bae KW, Choy WS. Use of the radial groove view intra-operatively to prevent damage to the extensor pollicis longus tendon by protruding screws during volar plating of a distal radial fracture. Bone Joint J. 2013;95B:1372-6.

18. Simic PM, Robison J, Gardner MJ, Gelberman RH, Weiland AJ, Boyer MI. Treatment of distal radius fractures with a low-profile dorsal plating system: an outcomes assessment. J Hand Surg Am. 2006;31:382-6.

19. Lutsky K, Boyer M, Goldfarb C. Dorsal locked plate fixation of distal radius fractures. J Hand Surg Am. 2013;38: 1414-22. 


\section{후방 전위된 원위 요골 골절의 후방 금속판 고정술}

\section{나기태 · 송석환 · 이윤민 · 강병민}

가톨릭대학교 의과대학 정형외과학교실

목적: 후방 전위된 원위 요골 골절을 두 가지 후방 금속판을 사용하여 치료하였으며, 두 군의 치료 결과를 비교하고자 한다.

방법: 후방 금속판 고정술을 시행한 원위 요골 골절 43예를 후향적으로 분석하였다. 비잠김 금속판을 사용한 24예를 1군 으로, 잠김 금속판을 사용한 19예를 2군으로 나누었다. 관절 운동 범위와 Green and O’ Brien 점수로 임상적 결과를 평 가하였으며, 방사선학적 평가로는 수술 직후 및 마지막 추시의 요측 경사, 요골 길이, 수장 경사 변화를 측정하였다.

결과: 골절 형태의 $\mathrm{AO}$ 분류상 $\mathrm{A}$ 형은 18 예, $\mathrm{B}$ 형은 4 예, $\mathrm{C}$ 형은 21 예이었다. 평균 관절 운동 범위는 1 군에서 굴곡 $65.0^{\circ}$, 신전 $65.3^{\circ}$, 척측 변위 $25.5^{\circ}$, 요측 변위 $20.8^{\circ}$, 회내전 $80.0^{\circ}$, 회외전 $80.4^{\circ}$ 이었으며, 2 군에서는 굴곡 $64.5^{\circ}$, 신전 $67.3^{\circ}$, 척측 변위 $30.6^{\circ}$, 요측 변위 $20.6^{\circ}$, 회내전 $81.4^{\circ}$, 회외전 $78.6^{\circ}$ 이었다. Green and O’ Brien score는 1 군 이 평균 94.4점, 2군이 92.2 점으로, 41예에서 만족스러운 결과를 얻었으며, 두 군 간의 통계적인 차이는 없었다. 수술 직후 및 마지막 추시 방사선학적 검사에서 요골 경사는 1 군이 각각 $23.9^{\circ}$ 와 $24.1^{\circ}, 2$ 군은 $24.2^{\circ}$ 와 $24.9^{\circ}$ 이었으며, 요골 길이는 1 군이 각각 $9.9 \mathrm{~mm}$ 와 $9.7 \mathrm{~mm}, 2$ 군이 $10.1 \mathrm{~mm}$ 와 $9.2 \mathrm{~mm}$ 이었다. 수장 경사는 1 군이 각각 $12.2^{\circ}$ 와 $13.1^{\circ}, 2$ 군 은 $14.8^{\circ}$ 와 $13.7^{\circ}$ 이었다. 모든 측정치들이 추시 중 통계학적으로 유의한 변화는 없었다. 금속판 내고정과 관련한 신전 건 파열의 발생도 없었다.

결론: 후방 전위된 원위 요골 골절에서 후방 금속판 고정술은, 본 연구에서 사용된 금속판의 경우 그 종류에 무관하게, 심각한 합병증이 없이 임상적 및 방사선학적으로 만족할 만한 치료 결과를 보였다.

색인단어: 원위 요골, 골절, 후방 금속판

접수일 2014년 2월 4일 수정일 2014년 3월 10일

게재확정일 2014년 3월 11일

교신저자 송석환

서울특별시 영등포구 63로 10,

가톨릭대학교 여의도성모병원 정형외과학교실

TEL 02-3779-1192, FAX 02-783-0252

E-mail sw.song@catholic.ac.kr 